\title{
TAX PROCEDURE LAW AND WITHIN THE CONTEXT OF ACCOUNTING STANDARDS OF TURKEY: DEPRECIATION APPLICATIONS OF TANGIBLE FIXED ASSETS
}

\author{
DOI: 10.17261/Pressacademia.2018.859 \\ PAP- V.7-2018(12)-p.72-80
}

Mustafa Canakcioglu

Kadir Has University, Istanbul, Turkey.

mustafa.canakcioglu@khas.edu.tr, ORCID: 0000-0001-7462-9934

To cite this document

Canakcioglu, M. (2018). Tax procedure law and within the context of accounting standards of Turkey: depreciation applications of tangible fixed assets. PressAcademia Procedia (PAP), V.7, p.72-80.

Permemant link to this document: http://doi.org/10.17261/Pressacademia.2018.859

Copyright: Published by PressAcademia and limited licenced re-use rights only.

\section{ABSTRACT}

Purpose- Businesses' investments in property, plant and equipment as well as the accuracy and the impacts of the depreciation procedure, applied to these assets and serve to the determination of end-of-period book values, are essential with respect to precise enlightenment of all parties utilizing financial statements. In this perspective, the purpose of the study is to examine the depreciation approaches of provisions in Turkish Accounting Standard 16 (TAS 16) and current Tax Procedure Law (VUK in Turkish abbreviation); and to present the similar and differentiating aspects in depreciation rate, depreciation period, determination of depreciable value, depreciation method and depreciation separation. Our study also includes explanations about the subject in Financial Reporting Standards for Large and Medium Sized Enterprises (BOBI FRS in Turkish abbreviation), for which there is an application requirement since 2018.

Methodology- The Tax Procedure Law in Turkey applied accounting standards within the framework of the depreciation methods and these methods are explored the depreciation costs calculation formats.

Findings- Both in the Tax Procedure Law and standards, although the name similarity calculations of depreciation methods, useful life, residual value, not as a tangible fixed asset is dissected into pieces all depreciation application can be made and in a different format all depreciated assets depreciation application can be made. Besides standard "production quantity method", also in the Tax Procedure Law. Conclusion- The fair for the first time to financial reporting standards will apply to businesses, and in particular a large number of tangible fixed asset has some difficulties with production enterprises. Calculation of the value of the entity remains some of these difficulties and declining-balance method can be applied. Therefore, such enterprises in the straight-line method of depreciation calculation featured our view that it would be more accurate of.

Keywords: Depreciation, TAS 16, Financial Reporting Standards for Large and Medium Sized Enterprises 12, property plant and equipment, accounting standards.

JEL Codes: M40, M41, M48

\section{VERGI USUL KANUNU VE TÜRKIYE MUHASEBE STANDARTLARI KAPSAMINDA MADDI DURAN VARLIKLARDA AMORTISMAN UYGULAMALARI}

\section{ÖZET}

Amaç- İşletmelerin maddi duran varlıklardaki yatııımları ve bu varlıklara ilişkin, dönem sonunda defter değerlerinin belirlenmesi için yapılan amortisman işlemlerinin doğruluğu ve işlemlerinin etkileri, finansal tablo kullanıcılarının doğru ve gerçek bilgilendirilmeleri açısından önemlidir. Bu çerçevede çalışmanın amacı Türkiye Muhasebe Standardı 16 (TMS 16) ile mevcut Vergi Usul Kanun'unda (VUK) yer alan hükümlerin amortisman konusundaki yaklaşımlarını inceleyerek amortisman oranında, amortisman süresinde, amortismana tabi değerin belirlenmesinde, amortisman yönteminde ve amortisman ayırmada benzer ve farkı yönlerini ortaya koymaktır. Çalışmamızda ayrıca 2018 den itibaren uygulama zorunluluğu getirilen Büyük ve Orta Boy Işletmeler için Finansal Raporlama Standardın (BOBi FRS) da, konuyla ilgili açıklamalara da yer verilmiştir.

Yöntem- Türkiye'deki Vergi Usul Kanunu ve uygulanmakta olan muhasebe standartları çerçevesinde amortisman yöntemleri ve bu yöntemlerin amortisman giderlerini hesaplama biçimleri incelenmiştir.

Bulgular- Hem Vergi Usul Kanunu'nda hem de standartlarda amortisman yöntemlerinin isim benzerliği olmasına rağmen hesaplamalardaki faydalı ömür, kalıntı değeri, bir maddi duran varlığın bütün olarak değil de parçalara ayrılarak amortisman uygulaması yapılabileceği ve amortismana tabi tüm varlıklara farklı bir biçimde kıst amortisman uygulaması yapılabileceği tespit edilmiştir. Ayrıca standartlardaki "üretim miktarı yöntemi", Vergi Usul Kanunu'nda da yer almamaktadır.

Sonuç- Gerçeğe uygun olarak hazırlanması gereken Finansal Raporlama Standartlarını ilk defa uygulayacak işletmelerde ve özellikle çok fazla sayıda maddi duran varlığa sahip üretim işletmelerinde bazı güçlüklerle karşılaşılabilir. Bu güçlüklerden bazılarını varlığın kalıntı değerinin hesaplanması ve azalan bakiyeler yönteminin uygulanması olabilir. Bu nedenle, bu tür işletmelerin amortisman hesaplamalarında normal amortisman yöntemini seçmelerinin daha doğru olacağı görüşündeyiz.

Anahtar Kelimeler: Amortisman, TMS 16, BOBI FRS 12, maddi duran varlıklar, muhasebe standartları. Jel Kodları: M40, M41, M48 


\section{GíRiş}

Muhasebe uygulamalarına yön veren standartlar, muhasebe kavram ve ilkelerinin, temel alınan yöntemleri belirleyen ve finansal tablolara yönelik ilkelerin uygulanmasını sağlayan esaslar ve kurallar bütünüdür (Erol ve Aslan, 2017:58). Bu kurallar çerçevesinde hazırlanan finansal tablolarda yer alan bilgilerin güvenilirliği kadar gerçeğe uygunluğu da önemlidir. Fakat aynı zamanda bu tablolardan hareketle ticari kârı belirleyerek, bu tutar üzerinden vergi almayı amaçlayan vergi kanunları, farklı düzenlemeler getirebilmektedir (Sarıay, 2012:110).

213 sayılı Vergi Usul Kanunu’nun 175 ve mükerrer 257. maddelerinin Maliye Bakanlığı'na verdiği yetkiye istinaden 26.12 .1992 tarihinde Maliye Bakanlığı tarafından yayımlanan ve uygulanması 01.01.1994 tarihinden itibaren zorunlu olan Muhasebe Sistemi Uygulama Genel Tebliğindeki düzenlemelerin ve finansal tabloların vergi kanunları çerçevesinde ele alınmışıı. İşletmelerin finansal durumunu vergi matrahını doğru tespit etmek amacıyla hazırlanması, değerleme hükümlerinin ihtiyari bırakıımış olması veya mevcut değerleme hükümlerinin uygulanma şekline ilişkin esasların açıklanmamış olması nedeniyle, finansal tabloların, kullanıııların bilgi ihtiyaçlarıı karşılayacak şekilde hazırlanması yerine, vergi mevzuatında yer alan esaslar dikkate alınarak raporlama yapılmasına neden olmuştur. Bunun sonucu olarakta finansal tabloların karşılaştııılabilir, gerçeğe ve ihtiyaca uygun sunum sağlama amacından uzaklaştığı görülmüştür (Yünlü, 2016).

Vergi mevzuatında ihtiyarı bırakılan değerleme hükümlerinden biri de amortisman konusudur. Mevzuata göre amortisman, bir yandan mükelleflere işletmelerinin değerlerini doğru ölçmeleri, işletmenin gerçek değerinin ortaya konulması anlamında bir muhasebesel ölçüt, diğer yandan da kazançları üzerinden adaletli bir şeklide vergi ödemeleri için getirilmiş hukuki bir mükellef hakkıdır (Erol ve Uyanık, 2014:93). Diğer bir deyişle, VUK'a göre amortisman ayrılması zorunlu değildir. Hem TMS hem de BOBI FRS de ise amortisman ayrılması zorunludur. Hatta bir maddi duran varlık kaleminin, toplam maliyetine göre önemli bir maliyeti olan her bir parçası da ayrı ayrı amortismana tabi tutulabilir. Maddi duran varlığın bu önemli bir parçasının faydalı ömrü de farklı olabileceği gibi bu parçaya uygulanabilecek amortisman yöntemi de farklı olabilir. Bu açıdan bakıldığında ülkemizde amortismana tabi duran varıkların maliyet bedelleri üzerinden ekonomik ömürleri dikkate alınarak yapılan amortisman uygulamalarındaki farkılık, hesaplanan amortisman paylarının da finansal tablolara yansımasında farklılığa neden olmaktadır.

Bu temel farklıık nedenin ise, her iki düzenlemenin, düzenleme amacının farklı olmasından kaynaklanmaktadır. Düzenleme amacının farklııı̆ı ise, amortismanın varlık nedenini farklı açılardan ele alınmış olmasıdır. Amortisman kavramının varlık nedeni dört temel esasa bağlanmaktadır (Öztürk, 2015:201). Bunlar değerleme, tüketim, yenileme ve dağııım yaklaşımlarıdır (Sevilengül, 2007:424-425).

Değerleme yaklaşımına göre amortisman, duran varlığın değerinde; "kullanma, zamanın geçmesi ya da önemini yitirme gibi nedenlere bağlı olarak meydana gelen azalmadır. Buna göre amortisman, bir aktif düzeltmesidir. Amortisman gideri de duran varlıkların dönem başındaki ve sonundaki "şimdiki değer farkından" oluşur.

Tüketim yaklaşımına göre amortisman, maddi duran varlık edinen işletme bir fayda stoku elde etmiş olur. Dönem içinde bu fayda stoku azalışının dönemlere dağııılması amortismanı oluşturur. Duran varlığın maliyeti duran varlı̆ın üretebileceği birim miktara bölünerek bir birim üretimin tüketeceği fayda stokunun parasal değeri bulunur ve üretim miktarına göre amortisman hesaplanır. Bu yaklaşıma göre amortisman gideri de duran varlı̆ı̆ fayda stokunun tüketilmesi ile ortaya çıkar.

Yenileme yaklaşımı amortismanın duran varlığın ekonomik ömrünün sonunda yenilenmesi için gerekli fonun tutulmasında bir araç olması esasına dayanır. Yaklaşıma göre amortisman, duran varlığın yenilenmesi için "fon biriktirilmesi" işlemidir.

Dağııım Yaklaşımına göre de amortismanı, duran varlıkların ediniminde yüklenilmiş olan maliyetlerin, bu varlıkların "ekonomik ömürleri içinde dönemlere dağıtılması" olarak görmektedir. Bu yaklaşımda katlanılan maliyetten hurda değerin düşülmesinden sonra kalan değer, yararlanma süresine bölünerek, dönemlere paylaştııılır. Buna göre amortisman katlanılan maliyetin dönemlere "dağııı" işlemidir.

İşletmeler hangi faaliyet alanında olursa olsun maddi duran varlıkların bilançolarının aktif toplamlarında önemli bir yere sahiptir. Tüm işletmeler açııından maddi duran varıkların amortisman yolu ile giderleştirilmesi vergi hukuku açısından bir yandan elde edilecek dönem kârı veya zararını etkilerken diğer yandan da üretim ve hizmet açısından üretilen mamullerin veya hizmetin maliyeti içinde yer alması açısından da önemlidir. Bu nedenle maddi duran varlıklarla ilgili olarak bunların aktifleștirilmiş tutarları üzerinden VUK, TMS 16 ve BOBi TFRS 12.Bölüm düzenlemeleri çerçevesinde ilgili yöntemlere göre amortisman ayrılması ve muhasebeleştirilmesi çalışmamııı konusunu oluşturmaktadır.

\section{LITERATÜR TARAMASI}

\subsection{Amortisman Kavramı}

Tarihte ilk envanter işlemlerinin Mısır'da mal takibi amacı ile yapıldığı bilinmektedir (M.Ö. 3400 Yılları). Eski Yunan medeniyetinde sikke paranın kullanılması ile envanter işlemlerinde maddi sorumluluk doğuran işlemler ortaya çıkmışıı (M.Ö.400-300). Illk yıpranma payı (amortisman) kavramına eski Roma kayıtlarında rastlanmışır (Avder, 2007). Ülkemizde ise, amortismanlarla ilgili ilk hukuki düzenleme, Cumhuriyet döneminde 27 Şubat 1926 tarihli, 755 sayııı Kazanç Vergisi Kanunu’nda ki 14. Maddesinde "Zarar hesabına geçirilmesi iktiza eden aşınma payı "amortisman" her ne suretle olursa olsun vesaiti sınaiye ve ticariye kıymetinin yüzde onunu geçemez" seklinde yer almışır.

Amortisman kelimesi Fransızca "amortissement" sözcüğünden gelmektedir. Kelimenin anlamı Fransızcada öldürmek, tüketmek, söndürmek anlamlarına gelen Latince kökenli "a mortir" kelimesine dayanır. Genel bir kavram olarak isimlendirilen amortisman, maddi duran varlıklar için "Amortisman", maddi olmayan duran varlıklar için "itfa" ve özel tükenmeye tabi varlıklar için "Tükenme Payı" gibi duran varlıkların türüne göre farklı terimlerle ifade edilmektedir (Dalkılıç ve diğerleri, 2012:33).

Iş̧letmede bir yıldan fazla kullanılan ve yıpranmaya, aşınmaya veya kıymetten düşmeye maruz bulunan gayrimenkullerle VUK'un $269^{\prime}$ uncu maddesi gereğince gayrimenkul gibi değerlenen iktisadi kıymetlerin, alet, edavat, mefruşat, demirbaş ve sinema filmlerinin birinci kısımdaki esaslara göre tespit edilen değerinin bu Kanun hükümlerine göre yok edilmesi amortisman mevzuunu teşkil eder. VUK'da amortismanın 
tanımı olmamasına karşın, Kanunun 313. maddesi bir duran varlığın amortismana tabi olabilmesi için, bazı şartları hükme bağlamıştır. Bu şartlar aşağıda verilmiştir.

$>$ Duran varlığın işletmede bir yıldan fazla kullanılabilmesi,

$>$ Duran varlığın yıpranma, aşınma ya da değerden düşmeye maruz bulunması,

$>$ Duran varlığın aktife kayıtlı olması,

$>\quad$ Duran varlığın belirli bir tutarın üzerinde olması

$>$ Taşınmazlar gibi değerlenen varlık olmasıdır.

Bu şartlara uygun kanunun 313. maddesindeki gayrimenkuller, alet, edevat, mefruşat, demirbaş ve sinema filmleri ile aynı kanunun 269. maddesi gereğince gayrimenkul gibi değerlenen iktisadi kıymetler (gayrimenkulleri tamamlayıcı unsurlar, tesisat ve makineler, gemi ve diğer taşıtlar, gayri maddi haklar) amortismana tabidir. VUK'un 314. maddesinde maddi duran varlıklar arasında yer almakla beraber, boş arazi ve arsalara amortisman ayrılmayacağı hükme bağlanmıştır.

TMS 16' da amortisman 6.paragrafta; Bir varlığın amortismana tabi tutarının, yararlı ömür süresince sistematik olarak dağıtılmasını şeklinde tanımlanmıştır. Yararlı ömür ise, bir varlığın işletme tarafından kullanılabilmesi beklenen süreyi veya ilgili varlıktan elde edilmesi beklenen üretim sayısı veya benzeri üretim birimini ifade eder. BOBI FRS 'de amortismanın tanımı bulunmamakla birlikte TMS 16 'daki tanım paragraf $12.25^{\prime}$ de ifade edilmiştir.

\subsection{Amortismana Tabi Değer}

İşletmenin aktifine maliyet bedeli ile kaydedilen varlıklar zaman içerisinde, yapılan bu kayıttaki maliyet değeri ile cari değeri arasında farklılıklar ortaya çıkmaktadır. Ayrıca, varlığın kullanımındaki değişiklikler, beklenmedik aşınma ve yıpranmalar ve teknolojik gelişmeler varlığın değeri ve kullanım ömrü üzerinde etkili olmaktadır. Böyle bir durumda; kayıtlı değerin, zamanın şartlarına uygun ve söz konusu varlığın kalan kullanım ömrü ile orantılı bir büyüklükte izlenmesi gerekmektedir. Bu nedenle, bir iktisadi kıymetin amortismana tabi değerinin tespit edilebilmesi için, amortisman kapsamının ve yönteminin belirlenmesinin yanı sıra bu varlığın değerinin, gerçeğe uygun bir biçimde saptanabilmesi de önemlidir (Öztürk, 2015:202).

\subsubsection{VUK'a Göre}

Vergi Usul Kanunu'na göre, maddi duran varlıkların aktifleştirilmesinde maliyet bedeli kavramı uygulanmaktadır. Maliyet bedeli ise, bu kanunun 262. maddesinde, iktisadi bir kıymetin elde edilmesi veya değerinin artırılması nedeniyle yapılan ödemeler ile bunlara ilişkin tüm harcamaların toplamı olarak ifade edilmiştir. Bu bağlamda VUK, amortismana tabi değerin belirlenmesinde, varlığın kalıntı (hurda) değerini dikkate almamaktadır. Ayrıca maddi duran varlıkların satın alınmasında kullanılan kredilerinden doğan faiz giderleri, vade farkları, kur farkları ve komisyon giderleri varlığın alındığı yılın dönem sonunda kadar maliyetine eklenir (Danıştay 4 üncü Daire 30.5 .1970 tarih, E.1965/2775, K. 1970/3255 sayılı karar).

VUK'nun 313. maddesine göre ancak belli bir tutarı aşan varlıkların amortismana tabi olmıyacağı da belirtilmiştir. Her yıl Maliye Bakanlığınca yayımlanan ve yeniden değerleme oranına göre belirlenen hadlerin (490 Sıra No.lu V.U.K Genel Tebliği ile 1.1.2018'dan itibaren $1.000 \mathrm{TL}$ ) üzerinde kalan varlıklar aktifleştirilerek amortisman uygulamasına tabi tutulur. Katma değer hariç olarak belirlenen bu sınırın altında kalan alet, edevat, mefruşat ve demirbaşlar amortismana tabi tutulmayarak doğrudan gider olarak kaydedilir.

\subsubsection{TMS Standartına Göre}

TMS 16'nın 7.paragrafına göre, bir maddi duran varlık kaleminin maliyeti, bu kalemle ilgili gelecekteki ekonomik yararların işletmeye aktarılmasının muhtemel olması ve ilgili kalemin maliyetinin güvenilir bir şekilde ölçülebilmesi durumunda varlık olarak finansal tablolarda yer alır. Bu açıklama doğrultusunda standart maddi duran varlıkların nelerden oluştuğuna dair tek tek bir açıklama yapmamıştır.

TMS 16, amortismana tabi tutarı "Bir varlığın maliyetinden veya maliyet yerine geçen diğer tutarlardan, kalıntı değerin düşülmesiyle bulunan tutar" olarak tanımlamaktadır. Buradaki "kalıntı değer" ise yine tanımlarla ilgili 6. paragrafta "Bir varlık tahmin edilen yararlı ömrünün sonundaki durum ve yaşına ulaştığında elden çıkarılması sonucu elde edilmesi beklenen tutardan, elden çıkarmanın tahmini maliyetleri düşülerek ulaşılan tahmini tutar" olarak belirtilmiştir.

TMS 16’ya göre, maddi duran varlıkların ilk aktifleştirilmesinde maliyet bedeli ölçüsü kullanılır. Bu varlıkların finansal tablolarda gerçeğe uygun değerle yer almalarının sağlanabilmesi için ilk alımından sonraki dönemlerde düzenli aralıklarla tekrar değerlemeye tabi tutulur. İşletmeler bu değerlemede ya "maliyet" ya da "yeniden değerleme" modelinden birisini seçmek zorundadır. Seçimi serbest olan bu modellerden hangisi seçilirse seçilsin, seçilen modelin maddi duran varlıkların tamamına uygulaması gerekmektedir.

Maliyet yönteminde bir maddi duran varlık kalemi ilk edinme kaydından sonra, finansal tablolarda maliyetinden birikmiş amortisman ve varsa birikmiş değer düşüklüğü zararları indirildikten sonraki değeri ile gösterilmektedir (TMS 16 paragraf 30). Bu yöntemde maddi duran varlıkların ilk kez aktifleştirilmelerinden sonra, varlıkların amortismana tabi tutularak net defter değeri ile gösterilmesi gerektiği ifade edilmektedir (Kıymetli, 2013:24).

Yeniden değerleme modelinde ise, gerçeğe uygun değeri güvenilir olarak ölçülebilen bir maddi duran varlık kalemi, varlık olarak aktifleştirildikten sonra, yeniden değerlenmiş tutarı üzerinden gösterilir. Yeniden değerlenmiş tutar, yeniden değerleme tarihindeki gerçeğe uygun değerinden, müteakip birikmiş amortisman ve müteakip birikmiş değer düşüklüğü zararlarının indirildikten sonra bulunan değerdir (TMS 16 paragraf 31). Yeniden değerlemeler, gerçeğe uygun değer kullanılarak bulunacak tutarın, kayıtlı değerden önemli ölçüde 
farklılaşmaya imkân vermeyecek şekilde düzenli aralıklarla yapılmalıdır. Yeniden değerleme modelinin kullanımında, gerçeğe uygun değerin tespitinde aktif bir piyasanın varlığı zorunludur. Eğer aktif bir piyasa yoksa söz konusu değerin bağımsız değerleme uzmanlarınca tespit edilmesi ve bu durumun finansal tablo dipnotlarında açıklanması gerekmektedir (Tuğay, 2014 :38).

\subsubsection{BOBi FRS'ye Göre}

TMS 16 standartlıyla birçok yönden uyum içinde olan BOBi FRS'de 12.Bölüm yer alan maddi duran varlık standardında da varlıklar ilk kayda almada maliyet bedeliyle ölçülür (BOBi FRS paragraf 12.6). Aktifleştirmeden sonraki varlıkların ölçümlerde de yine maliyet ya da yeniden değerlenmiş tutarı üzerinden değerlenir (BOBi FRS paragraf 12.15). Şayet bir varlık yeniden değerlemeye tabi tutuluyorsa, bu varlık ile birlikte varlığın yer aldığı maddi duran varlık sınıfındaki diğer varlıklar da yeniden değerlemeye tâbi tutulur (BOBi FRS paragraf 12.18). Amortismana tâbi tutar, maddi duran varlığın maliyet bedelinden ya da yeniden değerleme sonrası bulunan tutarından kalıntı değerin indirilmesi suretiyle belirlenir (BOBi FRS paragraf 12.24). Maddi duran varlı̆ı̆n amortismana tâbi tutarı faydalı ömrü süresince sistematik bir şekilde dağııııır. Faydalı ömür, bir varlı̆ın işletme tarafından beklenen kullanım süresini ya da işletme tarafından ilgili varlıktan elde edilmesi beklenen üretim veya kullanım miktarını ifade eder. Faydalı ömür ise, işletme tarafından gerçekçi tahminlere dayanılarak belirlenmelidir (BOBI FRS paragraf 12.25). Amortisman işlemine varlık kullanıma hazır olduğunda başlanır ve kullanılan gün esasına göre kıst amortisman hesaplanır. Varlı̆ıın finansal tablo dışı bırakılmasıyla da amortisman uygulamasına son verilir (BOBi FRS paragraf 12.26).

\section{ARAŞTIRMA YÖNTEMI}

İlk önce VUK'a ve standartlara göre amortisman yöntemlerinin yıllık amortisman hesaplamalarının nasıl yapıldığı ele alınacaktır. Ancak, hem TMS hem de вOBi FRS deki amortisman yöntemleri aynı olduğundan bu iki standarttaki yöntemler aynı başlık altında incelenecektir. Son olarakta normal amortisman yöntemi açısından VUK'taki ve standartlardaki bu yöntemin yıllık amortismanın hesaplama arasındaki farklılıkları açıklanacaktır.

\section{BULGULAR}

\subsection{Vergi Usul Kanunu Açısından Amortisman Yöntemleri}

VUK amortisman konusu ve amortisman ayırma yöntemleri Kanunu'nun 313-321. maddeleri arasında ele alınmıştır. 30.122003 tarih ve 25332 sayılı Resmi Gazete de yayımlanan 5024 sayılı yasayla yapılan değişiklikler ile, işletmelerin aktife kayıtlı amortismana tabi iktisadi kıymetlerin faydalı ömürleri ve normal amortisman oranları Maliye Bakanlığının yayımlayacağı ilgili tebliğlerle tespit ve ilân edileceği hükmü getirilmiştir. Bu durum VUK'nun 315. maddesinde de açıklanmıştır. Bu maddeye göre, Maliye Bakanlığı 333 Sıra Numaralı VUK Genel Tebliği ile amortisman oranlarını ve ömürlerini bir liste ile belirlemiştir. 28.04 .2004 tarihli Resmi Gazete'de 25466 sayı ile yayımlanan 333 no'lu tebliğ esas kalmak şartıyla bu oran ve sürelerle ilgili olarak bugüne kadar bu konuyla ilgili olarak 339, 365, 389, 399, 406, 418, 439 ve 458 Sayılı VUK tebliğleri yayımlanmıştır. Aktifleştirildiği yıldan itibaren amortisman süresinin başladığı maddi duran varlıklara uygulanabilecek ve VUK tarafından belirlenen amortisman yöntemleri ise; normal amortisman yöntemi, azalan bakiyeler amortisman yöntemi, madenlerde amortisman, fevkalade amortisman ve kıst amortisman uygulamasıdır

\subsubsection{Normal Amortisman Yöntemi}

Mükellefler amortismana tâbi iktisadî kıymetlerini Maliye Bakanlığının tespit ve ilân edeceği oranlar üzerinden itfa ederler. Illân edilecek oranların tespitinde iktisadî kıymetlerin faydalı ömürleri dikkate alınır (VUK, md.315).

\subsubsection{Azalan Bakiyeler Yöntemi}

Bu yöntemde, işletmelerin yatırım yıllarında fon gereksinimlerinin daha fazla olacağı düşünüldüğünde normal amortisman yöntemine göre ilk yıllarda daha fazla fon yaratarak işletmenin güçlü kılınması amaçlanmıştır (Tuğay, 2013:175). Yöntem, ilk yıllarda vergi avantajı sağlayarak yeni yatırımların yapılmasını ve mevcut yatırımların yenilenmesini teşvik ederek işletmenin verimliliğini ve likiditesini arttırabilir. Ayrıca son yıllarda yöntem değiştirmek suretiyle, son yıl amorti edilmesi gereken tutarların bir kısmını bir önceki yıl amorti edebilme imkanı tanımaktadır. Çünkü, VUK'a göre azalan bakiyeler yönteminden normal amortisman yöntemine geçiş serbestliği vardır (Deran ve Yakupçebioğlu, 2006).Bu usulde uygulanacak amortisman oranı \% 50'yi geçmemek üzere normal amortisman oranının iki katıdır. illk yıl maliyet bedeli üzerinden ayrılan amortisman tutarı sonraki yıllarda maddi duran varlığın maliyet bedeli ile o ana kadar ayrılmış olan birikmiş amortisman tutarı arasındaki fark üzerinden yada, diğer bir deyişle, bir önceki dönemin net defter değeri üzerinden amortisman ayrılır. Amortisman süresinin son yılına devreden tutarına ise, herhangi bir oran uygulamadan, o yıl tamamen yok edilir. Bu usulde amortisman süresi normal amortisman nispetlerine göre hesaplanır (VUK mükerrer md. 315).

\subsubsection{Madenlerde Amortisman}

Ülkemizde maden yataklarının mülkiyeti devletin hüküm ve tasarrufu altında bulunmaktadır. Dolayısıyla bu tür yatakları işleten gerçek ve tüzel kişilerin sahip oldukları maden yatakları değil, sadece bu yatakların işletme hak ve imtiyazlarıdır (Aksoylu, 2013:142). İşletme sebebiyle içindeki cevherin azalmasından dolayı maddi değerini kaybeden madenlerin ve taş ocaklarının imtiyaz veya maliyet bedelleri, ilgililerin, müracaatları üzerine bunların büyüklük ve mahiyetleri göz önünde tutulmak ve her maden veya taş ocağı için ayrı ayrı olmak üzere Maliye ve Sanayi Bakanlıklarınca belli edilecek nispetler üzerinden yok edilir (VUK, md.316). Kanunun bu maddesine göre madenlerde uygulanacak amortisman tutarı aşağıda gösterilen formülle hesaplanması gerekmektedir.

İmtiyaz veya Maliyet Bedeli

Amortisman Tutarı =

Görünür veya Muhtemel Rezerv x Yıllık Fiili Üretim 


\subsubsection{Fevkalade Amortisman}

Amortismana tabi olup; yangın, deprem, su basması gibi afetler neticesinde veya yeni icatlar dolayısıyla teknik verim ve kıymetleri düşerek veya cebri çalışmaya tabi tutuldukları için normalden fazla aşınma ve yıpranmaya maruz kaldığından değerini tamamen veya kısmen kaybeden; menkul ve gayrimenkullerle haklara, mükelleflerin müracaatları üzerine ve ilgili Bakanlıkların mütalaası alınmak suretiyle, Maliye Bakanlığınca her işletme için işin mahiyetine göre ayrı ayrı belli edilen "Fevkalade ekonomik ve teknik amortisman nispetleri” uygulanabilmektedir (VUK, md.317). Madde hükmünden anlaşılacağı üzere maddi duran varlıkların değerlerinde oluşan azalmanın amortisman yoluyla muhasebeleştirilmesi ancak fevkalade şartların ortaya çıkması durumunda mümkün olabilmektedir (Ayçiçek, 2011:126).

\subsubsection{Kıst Amortisman}

VUK'da binek otomobillerin amortismanı konusunda farklı bir düzenlemeye gidilmiștir. Kanunun 320. maddesinin ikinci fıkrasında, faaliyetleri kısmen veya tamamen binek otomobillerinin kiralanması veya çeşitli şekillerde işletilmesi olanların bu amaçla kullandıkları binek otomobilleri hariç olmak üzere, işletmelere ait binek otomobillerinin aktife girdiği hesap dönemi için ay kesri tam ay sayılmak suretiyle kalan ay süresi kadar amortisman ayrılacağı ve ilk yıl amortisman ayrılmayan süreye isabet eden bakiye değerin, itfa süresinin son yılında tamamen yok edileceği belirtilmiştir. Maddeye göre sadece binek otomobiller aktife girdikleri yılda kıst amortismana tabi tutulabilir. Diğer maddi duran varlıklar ilgili hesap döneminin son günü aktife girmiş veya tam yıl kullanılmamış olsalar bile, aktife girdiği yılın sonunda dönemin tamamında kullanılmış gibi amortismana tabi tutulurlar.

\subsection{Standartlar Açısından Amortisman Yöntemleri}

Standartların, amortisman konusuyla ilgili getirmiş olduğu önmeli yenilikler; duran varlıkların kalıntı (hurda) değerinin belirlenmesi ve tespit edilen bu değerin önemsiz olmaması durumunda varlığın maliyet bedelinden düşülmesi, tüm varlıkların amortismana tabi tutulma zorunluluğu ve bütün duran varlıklara kıst amortisman uygulaması yapılmasıdır (Büyükipekci ve Yiğit, 2016:226). Ayrıca, varlıkların yararlı ömürleri işletmelerin varlıktan beklediği faydaya göre belirlendiği için amortisman oranlarının işletmelerce serbestçe belirlenebilmesidir (TMS 16 paragraf 56-57; BOBi FRS paragraf 12.25).

VUK'a göre sadece binek araçlar için öngörülen kıst amortisman uygulaması TMS 16 ve BOBI FRS 12.bölüm de yer alan bütün maddi duran varlıklar için öngörülmüştür. Fakat her iki uygulama arasında anlayış farklııkları da yer almaktadır. VUK'nun kıst amortisman uygulamasında faaliyet ömrü yıl olarak esas alınmakta, standartlarda ise ay hesabı tam olarak uygulanmaktadır. VUK'a göre ilk yılda hesaplanmayan amortisman son yılın amortismanına ilave edilirken, standartlara göre: ilk yıldan kalan aylara ait amortisman, son tam yıldan sonraki yılın ilgili aylar için kayda alınmaktadır. Bu durum ise, işletmelerin faaliyet sonuçlarını etkilemektedir. (Elitaş, vd, 2009: 22)

Standartlarda sözü edilen “Doğrusal Amortisman Yöntemi” ve “Azalan Bakiyeler Yöntemi” VUK'un 315. maddesinde belirtilen yöntemlerle aynıdır. Standartlarda bu iki yöntemin dışında bir de "Üretim miktarı yöntemi"ne göre amortisman ayrılabileceğini belirtilmiştir. İşletmeler bu yöntemlerden varlığın gelecekteki ekonomik yararlarının beklenen tüketim biçimini en çok yansıtan yöntemi serbestçe seçebilirler.

\subsubsection{Normal (Doğrusal) Amortisman Yöntemi}

Maddi duran varlığın yararlı ömrü boyunca ve varlığın kalıntı değerinde bir değişiklik olmadığı sürece her dönemde eşit tutarlı olarak amortisman hesaplanır (Abdioğlu vd., 2014: 370). Varlığın bu yönteme göre hesaplanacak amortisman tutarı aşağıdaki formülle bulunur.

Yıllık Amortisman Tutarı = (Maliyet bedeli - Kalıntı değer) $x$ Normal amortisman oranı Normal amortisman oranı = 1/ Tahmini Yararlı Ömür

Örnek: ABC Sanayi A.Ş. 14.05.2017 tarihinde 13.000 TL maliyet bedelli bir demirbaş satın almıştır. Demirbaşın yararlı ömrü 5 yıldır. Kalıntı değeri 1.000 TL olarak tahmin edilmektedir. Bu bilgilere göre; Maliyet değeri: $13.000 \mathrm{TL}$, Kalıntı değer (-) : (1.000) TL, Amortismana tabi tutar : 12.000 TL, Yararlı ömür : 5 yıl ve Amortisman Oranı: \%20'dir.

Yıllık Amortisman Tutarı = 12.000 TL/ \%20 = 2.400 TL Demirbaşınn yararlı ömrü ve kalıntı değerinde bir değişiklik olmadığı takdirde yıllara göre amortisman tutarları şöyle olacaktır.

Tablo 1: Normal (Doğrusal) Amortisman Yöntemine Göre Amortisman Tablosu

\begin{tabular}{|l|c|c|c|c|c|}
\hline Yıllar & $\begin{array}{c}\text { Duran Varlığın } \\
\text { Maliyet Bedeli }\end{array}$ & $\begin{array}{c}\text { Yıllık } \\
\text { Oran }\end{array}$ & $\begin{array}{c}\text { Yıl Sonu } \\
\text { Amortisman Payı }\end{array}$ & $\begin{array}{c}\text { Birikmiş } \\
\text { Amortismanı }\end{array}$ & $\begin{array}{c}\text { Dönem Sonu Net } \\
\text { Defter Değeri }\end{array}$ \\
\hline 2017 & 12.000 & $\% 20$ & $1.600 *$ & 1.600 & 10.400 \\
2018 & 12.000 & $\% 20$ & 2.400 & 4.000 & 8.000 \\
2019 & 12.000 & $\% 20$ & 2.400 & 6.400 & 5.600 \\
2020 & 12.000 & $\% 20$ & 2.400 & 8.800 & 3.200 \\
2021 & 12.000 & $\% 20$ & 2.400 & 11.200 & 800 \\
2022 & 12.000 & $\% 20$ & $800 * *$ & 12.000 & 0 \\
\hline
\end{tabular}




\subsubsection{Azalan Bakiyeler Yöntemi}

Bu yöntemin uygulaması VUK'un uygulamasına benzer, fakat, standartta bu usulün uygulanması için azami ve asgari bir oran yoktur. Vergi mevzuatının aksine amortisman oranı dolayısıyla varlığın yararlı ömrünü belirlemek serbesttir. Yöntemde önemli olan, amortisman giderinin, yararlı ömür boyunca azalarak hesaplanmasıdır (TMS paragraf 50 ve BOBi FRS paragraf 12.25). Azalan bakiyeler yöntemi kendi içerisinde iki katlı azalan bakiyeler, formüllü azalan bakiyeler ve yıl sayıları toplamı (artan veya azalan oranlı) yöntemleri olmak üzere 3'e ayrılır. Standartlarda azalan bakiyeler için hangi yöntemin ve seçilecek yöntemin nasıl hesaaplanacağına dair bir bilgi yoktur. Sadece TMS 16 paragraf 62 ve BOBi FRS paragraf 12.29 'da, azalan bakiyeler yöntemi için "amortismanın gideri yararlı ömür boyunca azalır" şeklinde tanımlanmıştır. Bu nedenle, işletmelerin yukarıda belirtilen üç hesaplama yöntemlerinden bir tanesini seçmeleri mümkündür. Aşağıda azalan bakiyeler yönteminin uygulanmasında esas alınan farklı yöntemler kısaca açıklanacaktır.

\subsubsection{1. İki Katlı Azalan Bakiyeler Yöntemi}

Bu yöntemde, maddi duran varlığın maliyet değerinden kalıntı değer indirildikten sonra kalan değer normal amortisman oranının iki katı ile çarpılmak suretiyle hesaplanır. Yöntemle ilgili "Yıllık Amortisman Tutarı” formülü aşağıdaki gibidir (Kaya ve Atasel, 2017:144).

( (Maliyet değeri - Kalıntı değer) - Önceki Dönem Ayrılan Amortisman) x (Normal amortisman oranı x 2))

Örnek: ABC Sanayi A.Ş. 14.05.2017 tarihinde 13.000 TLmaliyet bedelli bir demirbaş satın almıştır. Demirbaşın yararlı ömrü 5 yıldır. Kalıntı değeri 1.000 TLolarak tahmin edilmektedir. Bu bilgilere göre; Maliyet değeri : $13.000 \mathrm{TL}$, Kalıntı değer (-) : (1.000) TL, Amortismana tabi tutar : 12.000 TL, Yararlı ömür : 5 yıl, Amortisman Oranı: \%20 X 2 =\%40'dır.

Tablo 2: İki Katlı Azalan Bakiyeler Yöntemine Göre Amortisman Tablosu

\begin{tabular}{|c|l|l|c|c|}
\hline Yıllar & \multicolumn{2}{|c|}{ Amortisman Hesaplama } & $\begin{array}{c}\text { Amortisman } \\
\text { Tutarı }\end{array}$ & $\begin{array}{c}\text { Birikmiş } \\
\text { Amortisman }\end{array}$ \\
\hline 2017 & $12.000 \times \% 40=4.800$ & $(4.800 / 12$ ay $) \times 8$ ay $=3.200$ & 3.200 & 3.200 \\
\hline 2018 & $\begin{array}{l}3.200+1.600=4.800 \\
12.000-4.800=7.200 \times \% 40=2.880\end{array}$ & $\begin{array}{l}(4.800 / 12 \text { ay }) \times 4 \text { ay }=1.600 \\
(2.880 / 12 \text { ay }) \times 8 \text { ay }=1.920\end{array}$ & 3.520 \\
\hline 2019 & $\begin{array}{l}1.920+960=2.880 \\
7.200-2.880=4.320 \times \% 40=1.728\end{array}$ & $\begin{array}{l}(2.880 / 12 \text { ay }) \times 4 \text { ay }=960 \\
(1.728 / 12 \text { ay }) \times 8 \text { ay }=1.152\end{array}$ & 2.112 \\
\hline 2020 & $\begin{array}{l}1.152+576=1.728 \\
4.320-1.728=2.592 \times \% 40=1.037\end{array}$ & $\begin{array}{l}(1.728 / 12 \text { ay }) \times 4 \text { ay }=576 \\
(1.037 / 12 \text { ay }) \times 8 \text { ay }=692\end{array}$ & 1.268 \\
\hline 2021 & $\begin{array}{l}692+345=1.037 \\
2.592-1.037=1.555 \times \% 40=622\end{array}$ & $\begin{array}{l}(1.037 / 12 \text { ay }) \times 4 \text { ay }=345 \\
(622 / 12 \text { ay }) \times 8 \text { ay }=415\end{array}$ & 10.100 \\
\hline 2022 & $\begin{array}{l}10.860+207=11.067 \\
12.000-11.067=\text { Kalan tutar } 933\end{array}$ & $(622 / 12$ ay $) \times 4$ ay $=207$ \\
933 & 760 & 10.860 \\
\hline
\end{tabular}

\subsubsection{Formüllü Azalan Bakiyeler Yöntemi}

Sistematiklik açısından bu yöntem diğer azalan bakiyeler yöntemlerine göre en ideali olarak kabul edilenidir. Zira, ne kalıntı değerin yüksek olması halinde amortismanın erken durmasına, ne de kalıntı değer sıfıra yakın olsa bile son yıl, daha önceki yıldan daha fazla amortisman ayrılmasına neden olur. Sistematik azaltmalarla hep defter değeri, kalıntı değere eşit hale gelir (Erol ve Uyanık, 2014:107). Bu yöntemde amortisman oranı aşağıdaki formüle göre hesaplanır (Dinç ve Atabay, 2018:70).

$$
\mathrm{r}=1-\sqrt[n]{H D / V D}
$$

Bu formülde; $r$ = amortisman oranı, $n=$ faydalı ömür, HD = kalıntı değer, VD = varlığın değerini, gösterir.

Örnek: Yararlı ömrü 4 yıl ve değeri 110.000 TL olan bir varlığın kalıntı değeri 10.000 TL olsun. Bu varlığın formüllü azalan bakiyeler yöntemine göre amortismanı şu şekilde ayrılacaktır ( $n=4, H D=10.000$, VD = 110.000 iken $r=0,45089$ olacaktır). 
Tablo 3: Formüllü Azalan Bakiyeler Yöntemine Göre Amortisman Tablosu

\begin{tabular}{|c|c|c|c|c|}
\hline Yıllar & $\begin{array}{c}\text { Duran Varlığın Dönem Başı Net } \\
\text { Defter Değeri }\end{array}$ & $\begin{array}{c}\text { Yıllık } \\
\text { Oran \% }\end{array}$ & $\begin{array}{c}\text { Yıl Sonu } \\
\text { Amortisman Payı }\end{array}$ & $\begin{array}{c}\text { Dönem Sonu Net } \\
\text { Defter Değeri }\end{array}$ \\
\hline 1 & 110.000 & 45,089 & 49.598 & 60.402 \\
2 & 60.402 & 45,089 & 27.234 & 33.168 \\
3 & 33.168 & 45,089 & 14.956 & 18.212 \\
4 & 18.212 & 45,089 & 8.212 & 10.000 \\
\hline
\end{tabular}

\subsubsection{Yıl Sayılarının Toplamı Yöntemi}

Bu yöntem kendi içinde azalan ve artan oranlı olarak uygulanır. Azalan oranlı uygulamada örneğin, yararlanma süresi 4 yıl olan bir maddi duran varlığın amortismanın ilk yıl için 4, ikinci yıl için 3 üçüncü yılı için 2 son yıl için 1 katsayısı verilir. Yatırımın maliyeti bu katsayıların toplamına bölünür ve bulunan sayı o yılın katsayısı ile çarpılarak yıllık amortisman tutarı bulunur (Sevilengül, 2007: 432-433).

Yıl sayıları : : $4+3+2+1: 10$

İtfa edilecek tutar : $110.000-10.000=100.000$

Tablo 4: Yıl Sayılarının Toplamı Yöntemine Göre Amortisman Tablosu

\begin{tabular}{|c|c|c|c|c|}
\hline Yıllar & $\begin{array}{c}\text { Duran Varlığın Dönem Başı Net } \\
\text { Defter Değeri }\end{array}$ & $\begin{array}{c}\text { Yıllık } \\
\text { Oran }\end{array}$ & $\begin{array}{c}\text { Yıl Sonu } \\
\text { Amortisman Payı }\end{array}$ & $\begin{array}{c}\text { Dönem Sonu Net } \\
\text { Defter Değeri }\end{array}$ \\
\hline 1 & 100.000 & $4 / 10$ & 40.000 & 60.000 \\
2 & 100.000 & $3 / 10$ & 30.000 & 30.000 \\
3 & 100.000 & $2 / 10$ & 20.000 & 10.000 \\
4 & 100.000 & $1 / 10$ & 10.000 & 0 \\
\hline
\end{tabular}

$\mathrm{Bu}$ yöntemin tam tersi olarak kullanılan artan oranlı amortisman yönteminde ise, yukarıda verilen örnekteki yıllık oranlar için yıllara küçükten başlayarak uygulanması yolu ile yıllık amortisman tutarı hesaplanır.

\subsection{3. Üretim Miktarı Yöntemi}

Üretim miktarı yönteminde beklenen kullanım ya da üretim miktarı üzerinden amortisman ayrılır (TMS 16, paragraf 62). Bu yöntemde maddi duran varlıkların üretebileceği ürünlerin miktarı önceden tahmin edilebildiğinde amortisman tutarının hesaplanmasına mümkün kılmaktadır. Tahmin edilen üretim miktarı her yıl değişebildiğinden ayrılacak amortisman tutarı da yıllar itibariyle değişiklik göstermektedir (Kaya ve Atasel, 2017:145). Üretim miktarı amortisman yönteminin nitelikleri aşağıdaki gibi özetlenebilir (Çankaya ve Yılmaz, 2014: 227-228).

Diğer amortisman ayırma yöntemleri süreyi baz alırken, üretim miktarına göre amortisman yönteminde duran varlığın çalışma yoğunluğunu gösteren iş ölçüsü dikkate alınır.

Üretim miktarı yöntemi değişken amortisman yöntemi olarak adlandırılabilmekte ve gerçekleşen kullanım ile değer kaybı ilişkisini daha iyi yansıttığı görülmektedir.

Üretim miktarı yöntemi, amortismanı zamanın değil, kullanım ve verimliliğin bir sonucu olarak kabul ettiği için, zaman bazlı durumlarda kullanılamaz.

Üretim miktarı yöntemi faaliyete dayalı maliyet sistemi kullanan işletmelerde faaliyetlerde varlık maliyetinin gerçek kullanımı dikkate alındığı için daha kolay uygulanabilir.

Üretim miktarı yönteminde ayrılacak amortisman tutarı, varlığın tahmin edilen üretim kapasitesiyle ilgilidir.

Sonuç olarak duran varlığın kullanımı fazla ise amortisman tutarı da fazla, kullanım az ise amortisman tutarı da az olur ve bu durumda amortisman giderleri işletmenin gerçek üretim sonuçlarını yansıtır. Üretim miktarı yöntemine göre amortisman oranının ve amortisman tutarının hesaplanması aşağıdaki gibi formüle edilebilir (Pamukçu, 2010:78).

$$
\begin{gathered}
\text { Amortisman Oranı }=\frac{\text { Maliyet Bedeli-Hurda Değeri }}{\text { Tahmin Edilen Ekonomik Ömür Boyunca Varlığın Üreteceği Birim Sayısı }} \\
\text { Amortisman Tutarı = Amortisman Oranı x Dönem İçinde Üretilen Birim Sayısı }
\end{gathered}
$$

Örnek: ABC Sanayi A.Ş. 14.05.2015 tarihinde 4.000 TL maliyet bedelli bir yazıcı satın almıştır. Yazıcının yararlı ömrü 5 yıldır. Kalıntı değeri 200 TL olarak tahmin edilmektedir. Yazıcı yararlı ömrü boyunca 50.000 adet baskı yapacaktır. 2015 yılında 7.000 adet, 2016 yılında 9.500 adet, 2017 yılında ise 9.000 adet baskı yapmıştır.

Amortisman Oranı $=(4.000-200) / 50.000=0,076$

Kullanım yılları itibariyle amortisman tutarları şöyle olacaktır: 
2015 yılı amortismanı $=7.000 \times 0,076=532$

2016 yılı amortismanı $=9.500 \times 0,076=722$

2017 yılı amortismanı $=9.000 \times 0,076=684$

\section{UYGULAMA FARKLILIKLARI}

Standartlarda amortisman ayrılması zorunlu iken, VUK'a göre bu uygulama ihtiyaridir. Muhasebe standartlarına göre faydalı ömür, işletme tarafından tespit edilirken VUK'da Maliye Bakanlığı tarafından belirlenmektedir. Standartlarda amortisman dönemi varlığın kullanıma hazır olduğunda başlamaktadır. Kullanılabilir olma ise, yönetim tarafından istenilen yer ve duruma getirilme olarak tanımlanmaktadır. Örneğin; parça parça olarak yurtdışından getirilmiş ama tek bir varlık olarak aktife kaydedilmiş; ancak, henüz montajı yapılmamış bir makina için amortisman ayrılması söz konusu olmayacaktır.Oysa VUK'da amortisman ayrılması için varlığın, aktife girmiş olmasını yeterlidir (EROL ve UYANIK, 2014:103).

VUK'da İktisadi kıymetin değerinin belli bir tutarı (2018 yılı için 1.000 TL) aşması durumunda aktifleştirilebilir, aksi takdirde gidere yazılırken, Standartlarda bir varlığın maddi duran varlık olarak sınıflandırılması için herhangi bir rakamsal sınırlandırma yoktur.

VUK'da varlığın bütünü amortismana tabidir. Parçalara ayrılamaz. Standartlarda ise, MDV'nin önemli olan her bir parçası ayrı ayrı amortismana tabi tutulabilir. Ayrıca, standartlara göre bina satın alındığında arsa payı ayrıştırılarak kaydedildiği için sadece bina amortismana tabi tutulur, arsa amortismana tabi tutulmaz. VUK'da böyle bir düzenleme yoktur. Arsa, bina maliyetinin içinde kabul edildiği için bina, arsası ile birlikte amortismana tabi tutulur (Şen ve Özbirecikli 2018:472-473).

VUK ve standartlardaki amortisman uygulamaları arasındaki bir diğer farlılık ise, kalıntı değeri ve bütün varlıklara uygulanacak olan kıst amortisman uygulamasıdır. Bir varlık tahmin edilen faydalı ömrünün sonundaki durum ve yaşına ulaştığında elden çıkarılması sonucu elde edilmesi beklenen tutardan, elden çıkarmanın tahmini maliyetleri düşülerek ulaşılan tahmini tutara kalıntı değeri denir (TMS paragraf 6 ve BOBI FRS EK 9). Muhasebe standartlarına göre amortismana tabi tutar varlığın defter değerinden kalıntı (hurda) değerin düşülmesi yoluyla bulunurken VUK'a göre amortismana tabi tutar maddi duran varlığın defter değeridir. Aşağıdaki tabloda hem kalıntı değerinin hem de kıst amortisman uygulamasının normal amortisman yöntemi çercevesinde VUK ve standartlara göre karşılaştırmalı uygulama tablosu verilmiştir.

Tablo 5: Normal Amortisman Yönteminin Karşılaştırma Tablosu

\begin{tabular}{|c|c|c|c|}
\hline Yıllar & $\begin{array}{c}\text { VUK NORMAL } \\
\text { Ayrılan Amortisman Tutarı }\end{array}$ & $\begin{array}{c}\text { TMS NORMAL } \\
\text { Ayrılan Amortisman Tutarı }\end{array}$ & FARK \\
\hline 2017 & 2.600 & $1.600^{*}$ & 1.000 \\
2018 & 2.600 & 2.400 & 200 \\
2019 & 2.600 & 2.400 & 200 \\
2020 & 2.600 & 2.400 & 200 \\
2021 & 2.600 & 2.400 & 200 \\
2022 & & $800^{* *}$ & -800 \\
\hline
\end{tabular}

Normal Amortisman Yöntemi'nin standartlar ve Vergi Usul Kanunu hükümlerine göre yapılan uygulama arasındaki fark 1.000 TL olarak gerçekleşmiştir. Bunun nedeni standarların hesaplamalarında, kalıntı değerinin maliyet değerinden düşülmesidir. VUK'da böyle bir uygulama olmadığından amortismana tabi tutar maliyet bedelidir. Bunun dışında 2017 yılında gerçekleşen 1.000 TL'lik fark ve 2022 yılında oluşan 800 TL'lik fark, standartlara göre amortisman hesaplamasına ilgili varlığı kullanılmaya başladığı aydan itibaren başlatması (Kıst Amortisman) ve ilk yılda ayrılmayan amortisman tutarını makinenin yararlı ömrünün bittiği yılı takip eden yılda dikkate alınmasından kaynaklanmaktadır. Ayrıca, diğer yıllarda oluşan farkların nedeni de, varlığın kalıntı değerinden kaynaklanmaktadır.

\section{SONUÇ}

2006 yılından günümüze kadar süre gelen TMS 16 standartını uygulayan işletmelerden çok asıl sorun, 1994'den beri VUK ve Muhasebe Sistemi Uygulama Genel Tebliğlerine göre amortisman uygulaması yapan işletmelerin ilk defa BOBi FRS'ye göre finansal raporlarının hazırlayacak olmasıdır. VUK'un amortisman uygulamasında sadece yöntem seçme ve azalan bakiyelerden normal amortisman yöntemine geçiş özgürlüğü çercevesinde hareket eden bu işletmeler, BOBi FRS'deki amortisman hesaplamalarında bir çok özgürlüğü sahip olacaklardır. Doğaldır ki ilk başta bu özgürlüğün beraberinde getireceği bir takım sorunlarlada karşılaşacaklardır. Bu sorunları, mevcut maddi duran varlıkları için her yıl yeniden gözden geçirilecek olan kalıntı değerlerini saptayacak olmaları, varlıklarının ekonomik ömürlerini ve buna göre uygalacakları amortisman oranlarını da kendilerinin belirleyecek olması, bütün maddi duran varlıklarda kıst amortisman uygulamasına geçecek olmaları, varlığın bütünü yerine parçalara ayrılarak ayrı ayrı amortismana tabi tutacak olmaları ve ayrıca binaların amortismanlarını arsa payından ayrıştırılmış bir şekilde hesaplayacak olmaları şeklinde sıralayabiliriz. Kendi içinde bile zaten dikkat edilmesi gereken azalan bakiyeler yöntemine göre hesaplanacak amortisman giderinin belirlenmesine bir de üçer aylık geçici vergi dönemleri eklendiğinde, özellikle çok fazla maddi duran varlığa sahip üretim işletmelerinde ilk uygulama yıllarında bazı karışıklıklara neden olabilir. Ancak, BOBi FRS'ye geçiş döneminde karşılacakları bütün bu zorluklara rağmen bu şirketlerin, uluslararası muhasebe standartlarına göre gerçeğe uygun bir şeklide hazırlayacakları finasal raporlarını, paydaşlarına sunacakları da unutulmamalıdır. 


\section{KAYNAKÇA}

Abdioğlu, H., Yumuşak, S., Uyar, E. (2014). Vergi Usul Kanunu ve Türkiye Muhasebe Standartlarına göre amortisman konusunun incelenmesi ve örnek uygulamaları. Yönetim ve Ekonomi Araştırmaları Dergisi - Sayı:23, s.364-397.

Aksoylu, S. (2013). Finansal raporlama standartları kapsamında maden işletmelerinde amortisman uygulamasının değerlendirilmesi. Eskişehir Osmangazi Üniversitesi iïBF Dergisi, Aralık 2013, Cilt 8, Sayı 3, s.137-156.

Avder, E. (2007). Geçmişten günümüze muhasebe mesleği. http://www.muhasebetr.com/yazarlarimiz/erdogan/008/

Ayçiçek, F. (2011). Değeri düşen maddi duran varlıkların ölçümlemesinde işletmeye özgü bir değer olarak: kullanım değeri. Mali Çözüm Dergisi, Sayı 103, s.121-131.

Büyükipekci, S., Yiğit, E. (2016). TMS-16’ya göre maddi duran varlıkların muhasebeleştirilmesi ve değerleme sürecine teorik bir bakış. Selçuk Üniversitesi, Sosyal Bilimler Meslek Yüksekokulu Dergisi Cilt:19 Sayı:2, s.219-231.

Çankaya, F., Yılmaz, Z. (2014). Üretim miktarına göre amortisman yönteminin değişken maliyetler ve kârlıık üzerine etkileri. Karadeniz Teknik Üniversitesi Sosyal Bilimler Dergisi, Sayı 8, s.221-242.

Dalkılıç, A. F., Cagle, N. M., (2012). Küçük ve orta büyüklükteki işletmeler için Türkiye Finansal Raporlama Standardı́nda (Kobi TFRS) amortisman uygulamaları: kurallardan ilkelere geçiş. i̇mir serbest muhasebeci mali müşavirler odası, dayanışma dergisi, s.31-40.

Deran, A., Sıtkı Yakupçebioğlu, N. S. (2006). Türk Vergi Mevzuatında amortisman muhasebesi. Mevzuat Dergisi, Yıl 9, Sayı 104, www.mevzuatdergisi.com/2006/08a/01.htm (21.04.2018 erişim).

Dinç, E., Atabay, E. (2018). Türkiye'deki yasal düzenlemelere göre amortisman uygulamaları ve vergi etkisine yönelik değerlendirme. Journal of Accounting, Finance and Auditing Studies 4/2, s.67-91.

Elitaş, C., Akyüz, Y., Bulca, H. (2009). Kıst amortisman uygulamasının uluslararası muhasebe standartları ve Türk muhasebe sistemi açısından karşılaştırılması. Mali Çözüm Dergisi, Sayı 94, s.17-32.

Erol, A., Uyanık, R. Y. (2014). Bir mükellef hakkı olarak amortisman müessesi içinde maddi duran varlık amortisman usullerinin Vergi Usul Kanunu Ve Türkiye Muhasebe Standartları açısından değerlendirilmesi. i̇MMMO mali çözüm Dergisi, s.91-112.

Erol, M., Aslan, M. (2017). Uluslararası muhasebe ve denetim standartlarının gelişmesi. Muhasebe ve Finans Tarihi Araştırmaları Dergisi Ocak 2017 (12), s.55-86.

Sarıay, i., (2012). Türkiye Muhasebe Standartlarına göre maddi duran varlıkların değerlemesine ilişkin uygulamalar. Electronic Journal of Vocational Colleges, Mayıs 2012, s.110-124.

Kaya, U., Atasel, O. Y., (2017). Türkiye Muhasebe Standartları ile Vergi Usul Kanunu açısından maddi duran varlıklarda amortisman uygulamalarının karşılaştıııması: literatürdeki farkılıklar üzerinde bir değerlendirme. Siyaset, Ekonomi ve Yönetim Araştırmaları Dergisi, Cilt:5, Sayı:4, s.137-155.

Kıymetli, Ş. İ. (2013). Maddi duran varlıklar (TMS 16) standardının üretim işletmelerinde satışların maliyetine etkileri. Çankırı Karatekin Üniversitesi İktisadi ve İdari Bilimler Fakültesi Dergisi, Cilt: 3, Sayı: 1, s.21-36.

Özbirecikli, M., Şen, I. K. (2018). BOBi FRS'nin muhasebe uygulamalarına getirdiği değişiklikler: BOBi FRS, TMS/TFRS ve mevcut muhasebe sistemi çerçevesinde bir inceleme. Muhasebe ve Vergi Uygulamaları Dergisi, Nisan Özel Sayı, s.462-484,

Öztürk, E. (2015). Maddi duran varlıkların raporlanmasında gerçeğe uygun değer hiyerarşisinin kullanılması. Yönetim ve Ekonomi Araştırmaları Dergisi, Cilt:13 Sayı:3, s.199-214.

Pamukçu, F. (2010). Maddi duran varlıklarda amortisman uygulamasının Türkiye Muhasebe Standartları ve Türk Vergi Mevzuatı açısından karşılaştııılması. Muhasebe Ve Denetime Bakış, sayı 32, s.67-84.

Sevilengül, O. (2011). Genel muhasebe. Ankara: Gazi Kitabevi.

Tuğay, O. (2013). Maddi duran varlıklarda amortisman uygulamalarının TMS 16 ve vergi mevzuatı açısından incelenmesi. Çukurova Üniversitesi IiBß Dergisi, Cilt:17.Sayı:2, s.167-187.

Tuğay, O. (2014). Maddi duran varlıklarda değer düşüklüğü, değer düşüklüğünün iptali ve muhasebeleştirilmesi işlemlerinin TMS 16/TMS36 ve vergi mevzuatı açııından incelenmesi. Ankara SMMMO Muhasebe ve Vergi Uygulamaları Dergisi, Cilt 7 sayı1, s.31-52.

Yünlü, M. (2016). Bağımsız denetime tabi olup TMS/TFRS uygulama kapsamında olmayan işletmeler için finansal raporlama standartları. Muhasebe ve Denetim Dünyası Dergisi, Cilt 1, Sayı 1, s.23-42. 